\title{
Hypouricemia - the simple key towards diagnosis in a case of purine nucleoside phosphorylase deficiency, a rare and severe disease
}

\author{
Hipouricemia - cheia către diagnosticul unui caz de deficit de purin \\ nucleozid fosforilază, o boală rară si severă
}

\author{
Alexis-Virgil Cochino* ${ }^{* 1}$, Jean-Louis Pérignon², Mihaela Bătăneanț ${ }^{3}$, Mihai \\ Craiu $^{1}$, Ioan Gherghina ${ }^{1}$, Margit Șerban ${ }^{3}$
}

1. University of Medicine and Pharmacy "Carol Davila" and Institute for Mother and Child Care "Alfred Rusescu” Bucharest, România; 2. Hôpital des Enfants Malades, Assistance Publique-Hôpitaux de Paris \& Université Paris 5, France; 3. University of Medicine and Pharmacy "Victor Babeș”" and Emergency Children's Hospital “Louis Țurcanu”, Timișoara, România

\begin{abstract}
We describe the case of a 15 month old boy, investigated for repeated and prolonged infections, associated to progressive neurological impairment. Immunological work-up found low immunoglobulin levels and decreased numbers of $T$ and $B$ lymphocytes, with a T-B-NK+ phenotype. Imaging showed lack of thymus and cerebral cortex atrophy. The key towards the diagnosis was plasma uric acid determination: hypouricemia suggested purine nucleoside phosphorylase deficiency, a very rare disease, with only 67 reported cases worldwide. Diagnosis was confirmed by enzyme activity measured using a radioisotopic method.

Keywords: hypouricemia;primary immunodeficiency;severe combined immunodeficiency;purine nucleoside phosphorylase deficiency

\section{Rezumat}

Este descris cazul unui pacient în vârstă de 15 luni, internat pentru infecții repetate și prelungite, asociate cu afectare neurologică progresivă. Evaluarea imunologică a detectat nivele serice scăzute ale imunoglobulinelor și populații de limfocite $T$ și B reduse, cu un fenotip T-B-NK+. Imagistica a arătat lipsa timusului și atrofie corticală cerebrală. Elementul cheie care a orientat diagnosticul a fost determinarea acidului uric seric: hipouricemia a sugerat deficit de purin nucleozid fosforilazăa, o boală foarte rară, cu doar 67 de cazuri raportate la nivel mondial. Diagnosticul a fost confirmat de măsurarea activității enzimatice printr-o metodă radioizotopică.

Cuvinte cheie: hipouricemie;imunodeficiență primară;imunodeficiență severă combinată;deficit de purin nucleozid fosforilază
\end{abstract}

Received: 20 ${ }^{\text {th }}$ August 2013; Accepted: 12 $2^{\text {th }}$ July 2014; Published: $31^{\text {st }}$ August 2014.

*Corresponding author: Alexis-Virgil Cochino, University of Medicine and Pharmacy "Carol Davila" and Institute for Mother and Child Care "Alfred Rusescu” Bucharest, România, e-mail: alexis_virgil@yahoo.com 
A 15 month old boy was referred to our unit due to persistent cough, anorexia, weight loss (3 $\mathrm{kg}$ within $2 \frac{1}{2}$ months) and modified behavior. He had been admitted to the referring hospital for vomiting, diarrhea, weight loss, irritability and hostility against strangers.

At presentation he was febrile, pale, wasted, with a weight below the $3^{\text {rd }}$ percentile for his age; he had no BCG scar (vaccination mandatory in Romania), no visible tonsils, and presented with a thrush, productive cough and rare crackles, but no respiratory distress. His skeletal examination presented some particularities (bilateral $2^{\text {nd }}-3^{\text {rd }}$ toes syndactyly and frontal bossing). Standing was difficult and his gait ataxic. He was very anxious and difficult to examine, but when left alone with his mother he was very apathetic and somnolent.

Initial laboratory tests showed mild microcytic anemia, variable lymphopenia (270-1400/ $\mu \mathrm{l})$, decreased immunoglobulins $-\mathrm{IgG}=3.49 \mathrm{~g} / 1$ (reference range, RR 4.53-9.16g/l), $\operatorname{IgA}=0.08 \mathrm{~g} / 1$ (RR 0.2-1 g/l), IgM=0.13 g/l (RR 0.19-1.46 g/1), $\mathrm{IgE}=0.36 \mathrm{UI} / \mathrm{ml}(\mathrm{RR}<50 \mathrm{UI} / \mathrm{ml})$, and Candida albicans as a cause for his thrush. Flow cytometric lymphocytes phenotyping showed marked decrease of total CD3+ (26 cells/ $\mu 1$; RR 18003000 cells/ $\mu \mathrm{l}), \mathrm{CD} 3+\mathrm{CD} 4+(8$ cells/ $\mu \mathrm{l}$; RR $1000-$ 1800 cells/ $\mu 1), \mathrm{CD} 3+\mathrm{CD} 8+(16$ cells/ $\mu \mathrm{l} ; \mathrm{RR} 800-$ 1500 cells/ $\mu \mathrm{l})$ and CD19+ populations ( 56 cells/ $\mu \mathrm{l}$; RR 700-1400 cells/ $\mu \mathrm{l})$, with only moderate decrease of CD16+CD56+ numbers (138 cells/ $\mu \mathrm{l}$; RR 200-600 cells/ $\mu$; relatively increased percentage, i.e. $61 \%$ ). Further laboratory tests excluded a secondary immunodeficiency. Liver function tests, renal function tests and electrolytes were all normal. Situated on step 4 of the multi-stage diagnostic protocol for primary immunodeficiencies (1), plasma uric acid was measured, being low at $0.6 \mathrm{mg} / \mathrm{dl}$. Imaging showed lack of thymic tissue (chest X rays, ultrasound), frontal and temporal cortical atrophy (computed tomography), normal spleen (ultrasound).
A diagnosis of severe combined immunodeficiency (SCID) was made, the patient was isolated and given $0.6 \mathrm{~g} / \mathrm{kg}$ intravenous immunoglobulins (IVIG), $3 \mathrm{mg} / \mathrm{kg} / \mathrm{d}$ cotrimoxazole, $6 \mathrm{mg} / \mathrm{kg} / \mathrm{d}$ fluconazole and symptomatic treatment. Purine nucleoside phosphorylase (PNP) deficiency was suspected on a) late-onset SCID, with progressive lymphopenia from the age of 7 months (documented during a mild respiratory intercurrence, initially neglected) but oligosymptomatic until the age of 1 year, b) concomitant progressive neurological impairment, c) low uric acid value. PNP deficiency was confirmed by an undetectable value for erythrocyte PNP activity $(<0.01 \mathrm{nmol} / \mathrm{min} / \mathrm{mg} \mathrm{Hb})$. This was assessed in hemolysates by a radioisotopic method with paper chromatography separation of substrates and products on Whatman P81 paper (2). The mean value for control population is $144 \pm 19 \mathrm{nmol} /$ $\mathrm{min} / \mathrm{mg} \mathrm{Hb}$. Gene sequencing was unavailable at the time of diagnosis.

Bone marrow transplantation was scheduled. The patient was HLA typed and a search for a matching donor began. During this period, the patient presented an acute autoimmune hemolytic episode (characteristic feature of PNP deficiency); unfortunately, after autoimmunity was controlled, he developed multiresistant Gram negative rods sepsis (Pseudomonas aeruginosa), with a fatal course.

Purine nucleoside phosphorylase deficiency is an autosomal recessive disorder affecting purine degradation and salvage pathways. It causes deoxyguanosine triphosphate (dGTP) build-up in the mithocondria, with apoptosis of vulnerable cells (i.e. central $\mathrm{T}$ lymphocytes, neurons, cerebellar Purkinje cells)(3). Patients typically present with severe immunodeficiency, neurological dysfunction and autoimmunity $(4,5)$. A recent review of the literature identified 67 cases of PNP deficiency from 49 families (6). Interestingly, this rare disease can be suspected in the presence of hypouricemia however, in some cas- 
es plasma uric acid has been found to be within the paediatric reference range, suggesting that PNP deficiency should not be ruled out in the absence of hypouricemia.

This paper reports the first case of PNP deficiency in Romania. It also shows that, even in the molecular genetics era, a simple test can sometimes be very usefull in directing the diagnosis process into the right direction.

\section{References}

1. de Vries E. European Society for Immunodeficiencies (ESID) members. Patient-centred screening for primary immunodeficiency, a multi-stage diagnostic protocol designed for non-immunologists: 2011 update. Clin Exp Immunol. 2012 Jan;167(1):108-19 DOI: 10.1111/j.1365-2249.2011.04461.x

2. Pérignon JL, Durandy A, Peter MO, Freycon F, Dumez Y, Griscelli C. Early prenatal diagnosis of inherited severe immunodeficiencies linked to enzyme de- ficiencies. J Pediatr. 1987;111(4):595-8. DOI: 10.1016/ S0022-3476(87)80129-4

3. Mansouri A1, Min W, Cole CJ, Josselyn SA, Henderson JT, van Eede M, et al. Cerebellar abnormalities in purine nucleoside phosphorylase deficient mice. Neurobiol Dis. 2012 Aug;47(2):201-9. DOI: 10.1016/j. nbd.2012.04.001

4. Hershfield MS, Mitchell BS. Immunodeficiency diseases caused by adenosine deaminase deficiency and purine nucleoside phosphorylase deficiency. In: ScriverCR, Beaudet AL, Sly WS, Valle D, editors. The metabolic and molecular bases of inherited disease. 8th ed. New York: McGraw-Hill; 2001:2585-625.

5. Grunebaum E, Cohen A, Roifman CM. Recent advances in understanding and managing adenosine deaminase and purine nucleoside phosphorylase deficiencies. Curr Opin Allergy Clin Immunol. 2013 Dec;13(6):6308. DOI: 10.1097/ACI.0000000000000006

6. Walker PL, Corrigan A, Arenas M, Escuredo E, Fairbanks L, Marinaki A. Purine nucleoside phosphorylase deficiency: a mutation update. Nucleosides Nucleotides Nucleic Acids. 2011 Dec;30(12):1243-7. DOI: $10.1080 / 15257770.2011 .630852$ 